\title{
Analysis of the impacts and challenges of Covid-19 on green sukuk in Indonesia
}

\author{
A.F. Suwanan, A.C. Putro, A. Triyanto, S. Munir* \& S. Merlinda \\ Universitas Negeri Malang, Malang, Indonesia
}

\begin{abstract}
The Covid-19 pandemic is the biggest challenge in sustainable development. Sustainable development requires large capital, and this capital is obtained from the financial market, which comes from investment. There are various investment activities in Indonesia. As a country where most of the population is Muslim, in investment, they must pay attention to Islamic principles and Islamic law. There are various innovations in Islamic investment or financing, one of which is the Green Sukuk. This research aimed to portray the impacts and challenges Green Sukuk created during the Covid-19 pandemic in Indonesia. Secondary data using journals, articles, books, Ministry of Finance data, and news provided by the Ministry of Finance as materials and references were used. This study indicated that there are impacts and challenges faced in issuing new Green Sukuk during Covid-19 pandemic.
\end{abstract}

Keywords: green sukuk, Covid-19, investment

\section{INTRODUCTION}

Economic development aims to increase economic growth, and in carrying out economic development, it is always good to pay attention to the surrounding environment. Economic development that is exploitative can damage the environment (Mubarok 2018). If economic development always pays attention to the environment, it will create a dignified community condition and also establish a just economy. In economic development, there is government intervention, especially to make various policies. As an initial step in economic development to increase economic growth, one of which is an investment. Currently, the development of investment activities is directed towards the Sharia system.

Indonesia, as a predominantly Muslim country, has excellent potential in Sharia investment. In connection with investment policies for economic development that pay attention to the environment and climate change. The Indonesian government issues a financial instrument that focuses on the environment and climate change, namely the Green Sukuk. The results of this green sukuk issuance will be used to finance green projects in five sectors, namely resilience to climate change for disaster-prone areas, sustainable transportation, energy and waste management, sustainable agriculture, and renewable energy spread across various ministries/agencies (DJPPR 2018). With the existence of Sharia financial instruments, namely Green Sukuk, it will result in the community being wiser in investing because in investing, they also think about using natural resources in a healthy and not excessive manner but can provide maximum results (Karina 2019). Green Sukuk is relevant because the use of proceeds from its issuance must be allocated to development that considers the environment so that government efforts to address the problem of climate change can be realized (Suherman 2019). The existence of an environmental Green Sukuk is expected to make other investments emulate the Green Sukuk.

${ }^{*}$ Corresponding author 
The Covid-19 pandemic has an impact on all economic activities. One of the impacts is in Islamic finance, so the Sharia financial industry must move quickly to overcome this problem and adapt and make the right strategy to survive the Covid-19 pandemic (Tahliani 2020). Therefore, the implementation of Green Sukuk in Indonesia has big challenges. However, Green Sukuk must see the problem of the spread of Covid-19 as a challenge that must be transformed into an opportunity to be better at implementing Green Sukuk Indonesia.

With this background, this research was conducted to expose the challenges of implementing Green Sukuk in Indonesia in facing the Covid-19 pandemic in Indonesia.

\section{LITERATURE REVIEW}

\subsection{Investment}

Developments, whether carried out by the state or companies, require capital. There are many ways that this can be done to obtain finance or capital, one of which is by investing. According to Sukirno (1997), investment can be defined as spending on investment or companies to buy goods and production equipment to increase the ability to produce goods and services available in the economy. Meanwhile, according to Sunariyah (2003), investment is obtaining one or more assets usually has a long term with the hope of getting benefits in the future. Investors generally will get feedback from the capital that has been submitted. There are so many investment instruments in Indonesia, including Islamic Sharia. There are so many alternative Sharia investments in Indonesia, namely:
a. Sharia Deposits
b. Sharia Mutual Funds
c. Retail Sukuk
d. Sharia stocks and others.

In general, Islamic investment financial institutions divide into two: the money market and the Islamic capital market. Sharia investment is an investment that is based on Islamic laws. In Indonesia, the Islamic financial market is commonly referred to as the interbank money market based on Islamic Sharia principles. Islamic money market (PUAS). There are two financial markets used in this principle.

a. In the form of an interbank mudharabah invests certificate (IMA)

b. Bank Indonesia Wadi'ah Certificate (SWBI)

In Indonesia there is also an Islamic capital market which was marked by the establishment of the Jakarta Islamic Index (JII) in 2000.

\subsection{Green sukuk}

Sukuk in Arabic terms is a form of trust certificate in Sharia type of investment. Sukuk has become very popular in the Islamic economy, sukuk has been recognized by the Arab community after an expansion of trade to other countries. Sukuk are identified as assets, rights and benefits, and services of project ownership. According to Islamic Sharia Council (2002), sukuk are long-term securities based on Sharia principles issued by the issuer. According to the law on State Sharia Securities (SBSN), sukuk are securities issued based on Sharia principles, as evidence of the share of investment in SBSN assets, both in rupiah and foreign currencies. The agency in charge of issuing state sukuk is a legal entity that has been established and is based on law.

The issuance of sukuk is a new innovation in Islamic finance, and therefore, it is prohibited touse usury and the prohibition of buying and selling as stated in Al-Qur'an Q.S Ali Imran: 130 and Al Baqarah 278-279. Meanwhile, Green Sukuk is a Sharia bond issued where all of the proceeds are intended to finance green projects that contribute to climate change mitigation and adaptation and to conserve biodiversity so that it is well preserved. Green Sukuk is relevant because in particular, 
the use of the proceeds from its issuance must be allocated to development that considers the environment so that government efforts to overcome the problem of climate change can be realized (Suherman 2019). The existence of an environmenronmental Green Sukuk is expected to encourage green investing. The capital resulting from the Green Sukuk issuance is entirely for environmental management so that the natural ecosystem is well preserved along with changes in environmental conditions.

\section{METHODS}

In understanding the impacts and challenges of Green Sukuk issuance in Indonesia, this research used a qualitative method. To analyze the result, we conducted a secondary data and literature review through journals, articles, books, Ministry of Finance data sets, and news provided by the Ministry of Finance as materials and references. This study also seeks references through theories that are relevant to the cases and problems being studied.

\section{RESULTS AND DISCUSSION}

The beginning of the Covid-19 virus pandemic occurred in early December 2019, which occurred in Wuhan, China. According to WHO (2020), the coronavirus has the advantage of spreading it very quickly because it spreads only in contact with people infected with the virus so that other people can be infected. This virus generally attacks the respiratory system in humans, especially in the lungs, with various symptoms, ranging from low-grade symptoms to severe symptoms. In research conducted by Krishnamoorthy et al. (2020), there are two types of coronaviruses in the world, namely MERS (middle east respiratory syndrome) and SARS (severe acute respiratory syndrome). Coronavirus is a novel disease or virus that has never been identified by the medical world before. Due to the novelty of the virus, handling protocols are still being researched. The virus is now spreading globally (Djalante 2020).

The rapid spread of the coronavirus has had very serious effects on all aspects of life. In fact, human life in this world must adapt to this virus. The most significant impact occurred in the country's economic sector. Whether they are developed countries or countries that are still developing, all countries have experienced economic downturns. The economic down-turns that have occurred throughout the world, especially in Indonesia, are caused by policies taken to cut the spread of the coronavirus. The implementation of policies in the form of lockdowns is applied throughout the world, especially in Indonesia, so that economic activity has been significantly impacted. As a result of the lockdown applied by countries in the export-import, tourism, and other sectors, the production network has been disrupted. In small areas of a country, Large-Scale Social Restrictions (PSBB) are implemented, resulting in decreased consumption and demand for goods and services, which causes an economic downturn to occur.

According to Nasution (2020), Covid-19 pandemic's impact has resulted in low investor sentiment towards the market, which ultimately leads the market towards a negative trend. Strategic fiscal and monetary measures are urgently needed to provide economic stimulus. As the cases of the Covid-19 pandemic develop, the market fluctuates in a negative direction. Not only that, the slow pace of Indonesia's export activities to China also has a significant impact on Indonesia's economy. The Covid-19 pandemic that occurred in Indonesia and worldwide has resulted in many losses in various sectors. But of the many industries that have suffered badly from the pandemic, there is one economic sector that has no impact from the Covid-19 pandemic. The Islamic Capital Market in Indonesia is one that has seen no impact from the pandemic. Prijambodo (2020) mentions that the impact of Covid-19 was felt in all capital market instruments, but Sharia instruments were more immune to pandemics. The Composite Stock Price Index (IHSG) recorded that the lowest point in five years, namely 3,938 and JCI on 19 March 2019, was recorded at 4,910 and Net Sell reached Rp 7.2 billion on the stock market. In Islamic debt instruments, sukuk are observed to be 
more resilient than bonds. Based on data from the Indonesia Composite Index, a comparison of the sukuk and conventional markets shows that the yield on the sukuk market has decreased by 2.5 percent while bonds have a deeper decline of 4.46 percent.

\subsection{Potential and development of Green sukuk in Indonesia}

The Islamic instrument that has recently been of concern to the Indonesian government is the Green Sukuk instrument. The Green sukuk has enormous potential in traditional markets with the Islamic financial market and can be the momentum to used prove that the Green sukuk is a real Islamic finance influence on the market. From the development of conventional system bonds, Green Sukuk is superior. According to Brahim (2018), Green sukuk has great potential to expand the market and become a bridge between conventional finance and Islamic finance. Among the many potentials that exist in Green Sukuk, several potentials are outlined as follows.

a. In 2029, Indonesia projects 419 trillion IDR in the issuance of sovereign sukuk.

b. The increase in Green Bonds in 2029 is estimated to increase by 339.38 USD.

c. Investor demand for Green sukuk is positive from year to year

d. In 2018, domestic investors reached 271.179.

Green Sukuk is an investment instrument that is Sharia in nature and moves towards environmental empowerment. Many investors are interested in it because it is in the form of Sharia. However, in the development of Green Sukuk in Indonesia, many challenges must be faced. According to the Financial Services Authority (OJK), several challenges must be faced by the Green Sukuk in Indonesia, which is engaged in maintaining the environmental sector, including the following:

a. The lack of financial institutions in identifying a risk that might impact the environment due to limited capacity of authority.

b. The lack of awareness of financial institutions causes high risk and lack of government roles in handling environmentally friendly projects.

c. There is a mismatch in the payment period because an environmentally friendly project is a long-term project.

d. Lack of information on environmentally friendly projects.

e. Lack of support from banks in supporting environmentally friendly projects.

Apart from the challenges above, Sukuk provides an opportunity for the public or Muslim or non-Muslim investors in Indonesia to invest. The proceeds from the state sukuk to be used as APBN financing. There has been an increase in the issuance and contribution of state sukuk in the APBN, it can be proven that the accumulated issuance of state sukuk in 2018 has reached Rp. 950 trillion with an outstanding per October 25, 2018 of 657 trillion IDR with an average issuance per year of 79 trillion (Ministry of Finance 2019). The potential of the issuance of Green Sukuk is enormous and can build the welfare of the people and the economy of the Indonesian nation. Every time the government issues a sukuk, it is always eaten up by market demand, which proves this instrument has much potential.

When Covid-19 pandemic occurred in Indonesia, the Green Sukuk instrument was not influenced by this pandemic. The impact of this pandemic on the Green Sukuk instrument's issuance was only on the issuance process, which was somewhat delayed because the government was focused on finding ways to deal with current conditions and the social restrictions that had occurred. The Indonesian government on 18 June 2020 reissued the global sukuk with a nominal value of 2.5 billion USD or in 35 trillion IDR (exchange rate 14 thousand). According to the Directorate General of Risk and Financing Management (DJPPR) of the Ministry of Finance, this global sukuk is issued with a five-year tenor of 750 million USD over 10 years amounting to 1 billion USD and a 30-year tenure of 750 million USD under the Wakalah agreement. Sukuk received tremendous demand from global investors to oversubscribe 6.7 times compared to the estimated emission target. 


\subsection{Retail sukuk and savings sukuk}

The state sukuk market with several investors reaching 243,364 people in the domestic sphere in 2018 with a total of 10 series since 2009 occurred in Retail Sukuk. A very large increase, it should be noted that at the beginning of the issuance of retail sukuk, the number of investors was only 14,295 (DPS 2018). Apart from the potential Retail Sukuk issuance, the government issued Savings Sukuk in the domestic market. Initial issuance attracted 11,338 investors issued in 2016 and increased in 2017 to 16,477 investors. The Covid-19 pandemic's impact on the issuance of Retail Sukuk and Savings is constrained by the social restrictions implemented. Th rough the Ministry of Finance through the Directorate General of Financing and Risk Management (DJPPR), the government officially offers SR-013 retail sukuk series from 28 August 2020 to 23 September 2020, from which the government hopes to get funds from the public of 5 trillion IDR. The results of the sukuk issuance by the government are used to increase funds. The coupon offered is $6.05 \%$ and can be used within a two-month holding period. It is evident that the potential of Green Sukuk in the Domestic market is large. However, the government is still focusing on issuing sukuk for the international market. This is meant by the issuance of the Green Sukuk in the international market so that the government can attract Green Bond investors in the world to invest in Green Sukuk, which has clear benefits.

\section{CONCLUSION}

The Covid-19 virus originates from the city of Wuhan, China. Coronavirus or Corona Virus Diseases is a new disease or virus that has never been identified by the medical world before. Thus, Covid19 virus spreads very quickly throughout the world due to a lack of knowledge about this virus. The rapid spread of the coronavirus has had very serious effects on all aspects of life. The most significant impact occurred in the country's economic sector. Whether they are developed countries or countries that are still developing, all countries have experienced economic downturns. The Islamic Capital Market in Indonesia is one that has had no impact from the pandemic. When Covid-19 occurred in Indonesia, the Green Sukuk instrument was not impacted by this pandemic. The impact and challenges of this pandemic to the Green Sukuk instrument's issuance were only in the issuance process, which was delayed because the government was focused on finding ways to deal with current conditions and the social restrictions that occurred.

\section{REFERENCES}

Anggraini, Y. 2018. Peran Green Sukuk Dalam Memperkokoh Posisi Indonesia Di Pasar Keuangan Syariah Global. Journal of Economic Islamics and Business. Volume 01.

Brahim, C. T. 2018. The Role of green Islamic sukuk to the promotion of sustainable development objectives. Journal of the New Economy, 01, 186-207

Djalante, R., Lassa, J., Setiamarga, D., Sudjatma, A., Indrawan, M., Haryanto, B., Mahfud, C., Sinapoy, M. S., Djalante, S., Rafliana, I., Gunawan, L. A., Surtiari, G., \& Warsilah, H. 2020. Review and analysis of current responses to COVID-19 in Indonesia: Period of January to March 2020. Progress in Disaster Science, 6, 100091. https://doi.org/10.1016/j.pdisas.2020.100091

Directoral General of Risk and Financing Management (DJPPR). 2018. Green Sukuk, Instrumen Investasi untuk Pembangunan Berkelanjutan

Direktorat Pembiayaan Syariah (DPS). 2018. Hasil Penjualan Sukuk Negara Ritel seri SR-010, Retriviewed from: https://www.djppr.kemenkeu.go.id/page/loadViewer?idViewer= 7791\& action=download

Islamic Sharia Council (2002). Fatwa nomor 32/DSN-MUI/IX/2002, Dewan Syariah Nasional Majelis Ulama Indonesia.

Karina, L. A. 2019. Peluang dan tantangan perkembangan green sukuk di Indonesia. In Proceeding of Conference on Islamic Management, Accounting, and Economics (Vol. 2, pp. 259-265). 
Krishnamoorthy, S., Swain, B., Verma, R.S. et al. SARS-CoV,MERS-CoV, and 2019-nCoVviruses: an overview of origin, evolution, and genetic variations. VirusDis. Springer. 2020. https://doi.org/10.1007/s13337-02000632-9

Ministry of Finance Republik of Indonesia. 2019. Green Sukuk Issuance Allocation and Impact Report

Mubarok, S. 2018. Islam dan Sustainable Development: Studi Kasus Menjaga Lingkungan dan Ekonomi

Berkeadilan. Dauliyah Journal of Islamic and International Affairs, 3(1), 129-146.

Nasution, Dito. 2020. Dampak pandemic covid-19 terhdap perekonomian Indonesia. Jurnal Benefit 5(2), (212-224).

Prijambodo, B. 2020. Potensi Investasi Keuangan Syariah Di Era Pandemi. webinar series: Komite Nasional Ekonomi dan Keuangan Syariah (KNEKS), 12 juni 2020

Suherman, S. 2019. Identifikasi Potensi Pasar Green Sukuk Republik Indonesia. HUMAN FALAH: Jurnal Ekonomi dan Bisnis Islam, 1(6).

Sukirno, S, 1997. Pengantar Teori Mikroekonomi, Edisi Kedua, Cetakan Kesembilan, PT.Raja Grafindo Persada, Jakarta.

Sunariyah. 2003. Pengantar Pengetahuan Pasar Modal. Yogyakarta. (UPP) AMP YKPN.

Tahliani, H. 2020. Tantangan Perbankan Syariah dalam Menghadapi Pandemi Covid-19. Madani Syari'ah, 3(2), 92-113.

WHO. 2020. Report of the WHO-China Joint Mission on Coronavirus Disease 2019 (COVID-19). 16-24. February 2020. World Health Organization. 